\title{
Stimulation of osteogenesis to fight osteoporosis
}

\section{Opinion}

Osteoporosis is not just a phenomenon of bone demineralization and related problems, such as increased bone fragility or problems with bone knitting. Osteoporosis is also a problem of reduction of the internal surface of spongy bone. It was calculated that the total bone surface area - the surface of all trabeculae in all bones-can be anywhere between 380,000 and $420,000 \mathrm{~m}^{2}$ in an adult. ${ }^{1-5}$ On such surface area, bone marrow and other bone components come into contact with trabeculae, including microcrystals of carbonate hydroxyapatite - a mineral bone component. On this surface area, the chemico-physical balance is maintained between the marrow, blood vessels and others bone components, and phosphate and trabeculae collagen. ${ }^{6-10}$ Obviously, that balance changes with the loss of trabeculae and minerals in the osteoporosis process. The changes are the greater the more developed osteoporosis. Another important problem is the transfer of elements from bones to soft tissues. ${ }^{11-18}$ In the process of osteoporosis, not all elements released from bones are excreted outside the body. Some of them flow with blood and other body fluids and may settle in various places in tissues and organs. ${ }^{19,20}$ This leads first to so-called hidden mineralization, and later, as a result of further crystallization, to overt mineralization (calcifications). ${ }^{21}$ Hidden mineralization can be observed only in the results of chemical analyzes; it consists of substituting elements (mainly $\mathrm{Ca}$ and $\mathrm{P}$ ) in biological structures in so-called crystallization centers. ${ }^{22-24}$

The harmfulness of such mineralization (of arteries, heart valves, joint cartilage, etc.), not to mention its potential carcinogenic effect, does not require detailed discussion. Therefore, stopping the progress of osteoporosis, its prevention, and, above all, elimination of osteoporosis entirely, is one of the most important medical problems, or even one of the biggest challenges for humanity. Different methods of fighting osteoporosis are widely known, including using high calcium medication and others substances. However, reconstruction of spongy bone trabeculae affected by osteoporosis cannot be done by administering calcium and phosphorus. These elements, delivered to a usually older organism (e.g. in the form of tablets), do not necessarily go to the bone. If they encounter crystallization centers in other places than bones - arteries, cartilage, etc.-they eagerly join biological structures there, ${ }^{24}$ promoting the formation of mineralization (calcifications). Considering the fact that osteoporosis, and especially elements derived from bones in osteoporosis, can mineralize tissues, ${ }^{18}$ additional doses of calcium and phosphorus introduced for the "treatment" of osteoporosis accelerate the formation of calcifications outside the bones, which can lead to many "accelerated" health problems. For the reconstruction of trabeculae we need collagen, with programmed crystallization centers where hydroxyapatite will crystallize again. It crystallizes in the bones from alkaline phosphatase produced by osteoblast mitochondria. This means that we should also "mobilize" osteoblasts to re-synthesize alkaline phosphatase.

When collagen is synthesized with crystallization centers (in the appropriate places of its structure) and alkaline phosphatase is present, the trabeculae will be reconstructed. The result will be strengthening of the spongy bone structure at sites affected by osteoporosis. How can we start this mechanism? In certain circumstances, it starts on

\author{
Volume 2 Issue 2 - 2018
}

\author{
Maciej Pawlikowski \\ AGH- Univ Science and Technology, Poland \\ Correspondence: Maciej Pawlikowski,AGH-Univ Science and \\ Technology, Cracow, Poland, Email mpawlik@agh.edu.pl \\ Received: February 26, 2018| Published: March 29, 2018
}

its own. This happens in bone fractures, when the "osteosynthesis" process that occurs in the body from the moment of bone formation to their full mineralization is "repeated" in a natural way. So what is the factor that creates osteogenesis in bone knitting? Can this mechanism be used to strengthen bones affected by osteoporosis? Prowadzone badania i obserwacje procesu zrostu kostnego sugerują, że tak ${ }^{6}$ - ten mechanizm można uruchomić. Dopracowanie metody i wejście w fazę jej aplikacji wymaga szeregu dalszych eksperymentów i dodatkowych czasochłonnych i kosztownych badań. Conducted research and observations of the bone knitting process suggest that yes; this mechanism can be started. ${ }^{6}$ Fine-tuning the method and reaching the phase of its application requires a series of further experiments and additional time-consuming, costly tests.

\section{Acknowledgement}

None.

\section{Conflict of interest}

The author declares there is no any conflict of interest.

\section{References}

1. Niedźwiedzki T, Pawlikowski MZ. Miany mineralogiczne zachodzące w obszarze gojenia złamań kości długich. Mineralogical phenomena observed at healing part of broken bones. Chirurgia Narz Ruchu i Ortop Pol. 1990. p. 277-281.

2. Niedźwiedzki T, Dąbrowski Z, Miszta H, et al. Bone healing after bone marrow stromal cell transplantation to the bone defect. Biomaterials. 1993;14(2):115-121.

3. Pawlikowski M. Mineralizacja organizmu człowieka żyjącego, (Mineralization of human living organism). Prace Mineral. 1987;79:121.

4. Pawlikowski M, Ryskala Z. Charakterystyka mineralogiczno-chemiczna fosforanowej mineralizacji wybranych naczyń tętniczych człowieka. (Mineralogical-chemical characteristic of phosphate mineralization of human arteries). Roczniki Nauk Dyd, WSP w Krakowie Prace Fizjologiczne; 1991. p. 81-104.

5. Pawlikowski M. Mineralizacja nowotworowa (Mineralization of cancer). W: Biomineralizacja i biomateriały. PWN, Warszawa 1991. p. 84-92.

6. Pawlikowski M. Kryształy w organizmie człowieka, (Crystals of human organism). Secesja. 1993.132 p.

7. Pawlikowski M. Sekrety mineralizacji tkanek (Secrets of tissue mineralization). PAN Kraków. 1995. 97 p.

8. Pawlikowski M. Preliminary results of dissolution of substances mineralizing human arteries. Arch Mineralog. 1999;52:195-210. 
9. Pawlikowski M, Pfitzner R. Zastosowanie metod mineralogicznych w badaniach tkanek człowieka. I. Sposoby badania mineralizacji. (Mineralogical methods useful for examination of human tissues). Przegl Lekarski. 1995;52:119-123.

10. Pawlikowski M, Pfitzner R. Zastosowanie metod mineralogicznych w badaniach tkanek człowieka. II. Mineralizacja struktur serca. (Mineralogical methods useful for examination of human tissues. Mineralization of heart structures). Przegl Lekarski. 1995;52:24-27.

11. Pawlikowski M, Pfitzner K, Skinner C. Cholesterol-mineral concentrations of the aneurysmatic wall. Acta Angiologica. 1995. p. 1-15.

12. Pawlikowski M, Pfitzner R. Mineralizacja serca i dużych naczyń, (Mineralization of heart and big blood vessels). Wyd IGSMiE PAN Kraków. 1999.142 p.

13. Pawlikowski M, Niedźwiedzki T. Mineralogia kości. (Mineralogy of bones). Wyd PAN Oddział w Krakowie. 2002. p. 128.

14. Pawlikowski M. Minerals in human blood vessels and their dissolution in vitro. In: Skinner HCW, Berger AW, editors. Geology and health. Oxford University Press; 2003. p. 155-158.

15. Pawlikowski M. Biomineralization of cancer tissues. 20th Int. Symp. Molecular and Physiological Aspects of Regulatory Processes of the Organism. Cracow, H Lach editors. Wyd Abaton Kraków. 2011. p. 190 191.
16. Pawlikowski M, Kwinta A, Zwolinska B, et al. Green fiber lasers in urology. Folia Med Cracov. 2013;53(2):23-34.

17. Pawlikowski M. Mineralizacja guzów nowotworowych płuc. Mineralization of lung cancer tumors. Auxiliary sciences in archaeology. Preservation of relicts and emvironmental engineering; 2013.

18. Pawlikowski M. Osteoporosis as a source of tissue mineralization. Research on osteoporosis therapy and dissolution of arterial mineralization. Jour Life Science. 2014;8:610-625.

19. Pawlikowski M. Biomineralogy of osteoporosis. Academia Journal of Biotechnology. 2016;4:138-144.

20. Pawlikowski M. Biomineralogical investigation of apatite piezoelectricity. Traumatologia \& ortopedia Rosiji. 2016;2(80):58-63.

21. Pawlikowski M. Electric phenomenon in bones as a result of piezoelectricity of hydroxyapatite. Arch Clin Biomed Res. 2017;1 (3):132-139.

22. Pawlikowski M. Biomineralogy of angiogenesis. Arch Clin Biomed Res. 2017;1(4):161-167.

23. Pawlikowski M, Miler M. Biomineralogy of selected skin cancer. SM Dermatolog J. 2017;3(3):1015-1017.

24. Pawlikowski M. Centers of Human Tissue Biomineralization (Calcification). Cardiol Cardiovascmed. 2017;1(6):252-262. 